\title{
POPULATION POLYMORPHISM OF THE ALFALFA NODULE BACTERIA (Sinorhizobium meliloti) FOR THE GENES ENCODING FOR SYMBIOTIC EFFICIENCY AND COMPETITIVENESS
}

\section{O.P. ONISHCHUK, O.N. KURCHAK, E.P. CHIZHEVSKAYA, N.A. PROVOROV, B.V. SIMAROV}

All-Russian Research Institute for Agricultural Microbiology, Federal Agency of Scientific Organizations, 3, sh. Podbel'skogo, St. Petersburg, 196608 Russia, e-mail olony@yandex.ru

Acknowledgements:

Supported by Russian Foundations for Fundamental Research (grant № 14-04-01441), EurAsEC Program (Contract 14.M04.12.0011) and Russian Science Foundation (grant № 14-26-00094)

Received March 30, 2015

\begin{abstract}
The most important traits of nodule bacteria (rhizobia), which are tested for selection of commercially valuable strains are the symbiotic efficiency (ability to increase the mass of the inoculated host plants due to intensive fixation of molecular nitrogen) and competitiveness (ability to inoculate the plants in the presence of other rhizobia strains of the same species). By PCR analysis of alfalfa rhizobia (Sinorhizobium meliloti) of various origins we for the first time showed polymorphism of natural populations for genes Smc03879 or phbA (negative regulator of the effective symbiosis, encodes for synthesis of poly- $\beta$-hydroxybutyrate) and Sma0907 or cmp-107 (involved in the competition for nodultion). The population of the Uralsk region of Kazakhstan living in the impoverished saline soil, phbA gene was detected in $100 \%$ of the strains, while population of the rich Chernozem soil of the Ternopil region of Ukraine in only $82.2 \%$ of the strains. Even lower occurrence of $p h b A(30.8 \%)$ is characteristic of the strains isolated from alfalfa nodules collected in the Ternopil region. This polymorphism may reflect a low adaptive value for conversion of $\mathrm{C}$ compounds into poly- $\beta$-hydroxybutyrate for rhizobia strains from the Ternopil region in comparison with the strains of the Uralsk region. Participation of gene $p h b A$ in the control symbiotic efficiency is confirmed by the fact that the gene nifH, which encodes for the structure of the small subunit of nitrogenase, but does not affect the intensity of its synthesis, differences in polymorphism between strains of two populations were not identified. The absence of polymorphism for gene Smb21375 or eff-798 in all studied populations may be due to the fact that it encodes an $\mathrm{ABC}$ transporter required for the uptake by bacteria the broad range of essential nutrients obtained from both the host plant or from the soil. An increased incidence of effective symbionts among strains lacking gene $p h b A$, indicates the prospects to use the molecular probes containing this gene for the selection of practically important rhizobia genotypes that can provide the plant host with the significant amounts of fixed nitrogen.
\end{abstract}

Keywords: legume-rhizobia symbiosis, nodule bacteria, nitrogen fixation, symbiotic efficiency, competitiveness, population polymorphism, PCR analysis.

Nodule bacteria (rhizobia) that form $\mathrm{N}_{2}$-fixing symbioses with legumes are the most widely used in agriculture microorganisms: the scope of their annual production as part of biological products for legumes inoculation is measured by hundreds of millions of hectares [1]. Until recently, rhizobia strains for biological preparations were obtained by analytical selection methods, by their isolation from soil and plant nodules. Using transposon (Tn5) mutagenesis in alfalfa rhizobia (Sinorhizobium meliloti), a collection of eff-gene mutants that increase bacterial symbiotic efficacy (SE), i.e. their ability to increase productivity (biomass, the amount of accumulated nitrogen, seed yield) in inoculated plants, was obtained [2]. Many of these genes identified as negative symbiosis regulators encode plant C-compounds metabolism including their transport into cells (eff798), storage in the form of poly- $\beta$-hydroxybutyrate $(p h b A)$ and spending for 
polysaccharide synthesis (exoZ, $r k p C$, eglC). These genes are located in different parts of $S$. meliloti (chromosome megaplazmidy) genome which is a prerequisite for their use in the construction of strains with increased SE [3]. The cmp-genes that determine the ability of rhizobia to compete for nodulation with less active native soil strains are also of great interest for strain construction [4]. In this case, the promising sources are natural eff- and cmp-rhizobia populations.

In this article, we demonstrate $S$. meliloti population polymorphism for genes controlling symbiotic efficiency and competitiveness, which can be used for selection of commercially valuable rhizobia strains.

Technique. Using the standard method [5], alfalfa nodule bacteria strains (Sinorhizobium meliloti) were isolated from saline soils of Uralsk Region (Kazakhstan), from the chernozem soil of Ternopil Region (Ukraine), and from the nodules of various alfalfa species (Medicago lupulina, M. sativa) growing in these areas. The genes controlling economically valuable symbiotic features have been identified earlier by analyzing the Tn5-mutant effective SKhM1-105 and SKhM1-188 strains with enhanced symbiotic efficiency (eff-798 and phbA) or decreased competitiveness (cmp-107) [2, 6, 7].

The following primers were used for PCR amplification of DNA fragments containing the genes studied:

Smb21375 (eff-798) - 5'-GAGAACAGCCGGGAGGAAA-3' and 5'-

CAGAACACAGCAGCCAAAGC-3'

phbA (eff-152) - 5'-CCTTCGGCAATACTCTCGC-3' and 5'-GTTGAGACCCGAAGCGTTG-3'

Sma0907 (cmp-107) - 5'-CCACCCTCCAGATCCAAGGT-3' and 5' CCTACGAGCTTTCCGGTCTC-3'

PCR protocol was as follows: preliminary denaturation $-3 \mathrm{~min}$ at

$95{ }^{\circ} \mathrm{C}$; 30 cycles - denaturation $30 \mathrm{sec}$ at $94{ }^{\circ} \mathrm{C}$, primer annealing $30 \mathrm{sec}$ at $54{ }^{\circ} \mathrm{C}$, DNA synthesis $1 \mathrm{~min}$ at $72{ }^{\circ} \mathrm{C}$; final DNA synthesis -5 min at $72{ }^{\circ} \mathrm{C}$ (Thermocycler $\mathrm{C} 1000^{\mathrm{TM}}$, Bio-Rad, USA; CCU Genomic technology and cellular biology of the All-Russian Research Institute for Agricultural Microbiology). The resulting PCR products were separated on $1 \%$ agarose gel according to the standard method [8]. The lysates of rhizobia strains studied were used in PCR as DNA matrices. For this purpose, fresh bacterial culture was inoculated into $20 \mathrm{ml}$ of lysis buffer $(0.25 \mathrm{mM} \mathrm{NaOH}$; $0,25 \%$ SDS $)$, denatured in PCR machine $\left(95^{\circ} \mathrm{C}, 15 \mathrm{~min}\right)$, then $180 \mathrm{ml}$ of double distilled water was added, the resulting liquid was centrifuged for $1 \mathrm{~min}$ and stored at $-20^{\circ} \mathrm{C}$. Chromosomal IGS locus (region between the 16S and 23S rRNA genes), and the plasmid locus containing the nifH gene (encoding the small nitrogenase subunit) were analyzed as previously described [9].

Symbiotic efficacy of $S$. meliloti strains was studied in sterile microvegetation experiments in alfalfa (M. sativa) var. Vega [5].

Student's $t$-test was used for statistical data processing [10]

Results. To study population variability of alfalfa ( $S$. melilot $i$ ) rhizobia for the genes of efficacy and competitiveness depending on the environmental conditions (soil type, possibility of symbiosis), eff-798, phbA and cmp-107 polymorphism was analyzed in isolates from contrast different soils: the poor, saline soil of Uralsk Region of Kazakhstan without vegetation and the rich chernozem soil of Ternopil Region of Ukraine where numerous populations of black medick and alfalfa (M. lupulina and M. sativa) grow.

Data analysis (Table 1) demonstrated the presence of eff-798 (encodes ABC-transporter that provides the C-compounds entry into bacterial cells) in all $S$. meliloti strains regardless of the source of their isolation. The phbA- 
containing DNA fragment (encodes $\beta$-ketotiolase involved in bacterial accumulation of poly- $\beta$-hydroxybutyrate) is present in all strains of Uralsk Region soil but only in $82.2 \%$ of Ternopil Region soil strains. Even lower occurrence of phbA $(30.8 \%)$ is characteristic for the strains isolated from alfalfa nodules collected in Ternopil Region.

1. Occurrence of efficacy and competitiveness genes among Sinorhizobium meliloti strains of different origin

\begin{tabular}{|c|c|c|c|}
\hline \multirow{2}{*}{ Strain origin (their number) } & \multicolumn{3}{|c|}{ Proportion of strains with identified gene, $\%^{*}$} \\
\hline & eff- 798 & phbA & cmp-107 \\
\hline Uralsk region, soil (24) & 100 & $100^{\mathrm{a}}$ & $91.7 \pm 5.6^{\mathrm{a}}$ \\
\hline Ternopil region, soil (46) & 100 & $82.2 \pm 5.7^{b}$ & $84.8 \pm 5.3^{\mathrm{a}}$ \\
\hline Ternopil region, nodules (13) & 100 & $30.8 \pm 12.8^{\mathrm{c}}$ & $52.8 \pm 13.8^{\mathrm{b}}$ \\
\hline
\end{tabular}

Logically, the rhizobia $p h b A$ polymorphism in Ternopil Region population may reflect a reduced bacteria ability to accumulate carbon in the form of poly-hydroxybutyrate due to the switching on symbiotrophic carbon nutrition, carbon excessively supplied by plants. Probably, bacteria circulation among carbon-rich chernozem soil and plants contributes to selection weakening in favor of the strains actively accumulating reserve constituents. At the same time, the selection in favor of this feature which determines the $p h b A$ homogeneity of Uralsk Region population can provide its maximum survival in nutrient-poor saline soil devoid of vegetation. The absence of polymorphism for gene eff-798 in studied populations may be due to the fact that it encodes an $A B C$ transporter required for the bacteria uptake of the broad range of essential nutrients obtained both from the host plant and the soil.

Analysis of $S$. meliloti SE (symbiotic efficacy) in microvegetation experiments demonstrated the efficacy of all strains in which gene phbA has not been detected (inoculation significantly increased the dry weight of alfalfa var. Vega), while $29 \pm 8.1 \%$ of strains containing this gene were ineffective. However, SE extent does not depend on the presence of gene phbA in efficient strains, which may be associated with the varying of the genetic background for this gene expression.

In both $S$. meliloti soil populations, equally high polymorphism in gene cmp-107 was identified in which Tn5-mutation reduces bacteria competitiveness (see Table 1). At the same time, the gene is less common among the nodule isolates collected in Ternopil Region than among soil isolates. This suggests the participation of gene cmp-107 encoding a protein with unknown functions in bacteria competition not only for bacterial but also for soil ecological niches.

2. Parameters of the structure of igs and nifH Sinorhizobium meliloti soil and nodule subpopulations loci (Ternopil Region)

\begin{tabular}{|c|c|c|c|}
\hline \multirow{2}{*}{ Locus } & \multirow{2}{*}{ Parameter } & \multicolumn{2}{|c|}{ Strain origin (number) } \\
\hline & & soil (40) & nodules (13) \\
\hline \multirow[t]{3}{*}{$\overline{\text { IGS }}$} & Genotype number (per strain number, \%) & $5(12.5 \%)$ & $6(46.1 \%)$ \\
\hline & Diversity index & 0.384 & 0.798 \\
\hline & Proportion of dominant genotype, $\%$ & $77 \pm 6$ & $27 \pm 13^{*}$ \\
\hline \multirow[t]{3}{*}{ nifH } & Genotype number (per strain number, \%) & $3(7.5 \%)$ & $4(30.8 \%)$ \\
\hline & Diversity index & 0.486 & 0.489 \\
\hline & Proportion of dominant genotype, $\%$ & $63 \pm 8$ & $69 \pm 13$ \\
\hline
\end{tabular}

During experimental tests on rhizobia polymorphism analysis using the markers not related to the quantitative symbiosis activity expression directly, it was found (Table 2) that, first, the variation in locus IGS for nodule isolates is higher than for the rhizosphere which reflects the previously described general increase in rhizobia population polymorphisms in the transition from soil to 
the nodule niche [9]; second, no interpopulation differences were found in locus nifH which encodes the small nitrogenase subunit but is not involved in the quantification of nodule nitrogen-fixing activity. Thus, the difference between soil and nodule subpopulations in the presence of genes phbA and cmp107 are determined precisely by their participation in the control of quantitative symbiosis features.

Earlier, a number of genes controlling symbiotic efficacy [11-17] and competitiveness [18-22] have been described, but the studies of these genes population polymorphisms have not been performed.

Thus, we for the first time showed population polymorphism of alfalfa nodule bacteria (Sinorhizobium meliloti) in the genes controlling economically valuable features of symbiotic efficacy ( $p h b A)$ and competitiveness (cmp-107). High variability of the population of the nutrient-rich Ternopil Region chernozem soil in gene $p h b A$ which controls poly- $\beta$-hydroxybutyrate synthesis may be related to high availability of carbon obtained due to heterotrophic or symbiotrophic nutrition which reduces the selection intensity in favor of the strains accumulating $\mathrm{C}$-compounds actively. The polymorphisms analysis for the genes that act as negative regulators of symbiotic efficacy can be used for the selection of perspective strains for legumes inoculation.

\section{REFERENCES}

1. Tikhonovich I.A., Kruglov Yu.V., Kozhemyakov A.P., Chebotar' V.K., Kandybin N.V., Laptev G.Yu. Biopreparaty $v$ sel'skom khozyaistve [Biologicals in agriculture]. Moscow, 2005.

2. Sharypova L.A., Onishchuk O.P., Chesnokova O.N., Fomina-Eshchenko J.G., S i marov B.V. Isolation and characterization of Rhizobium meliloti Tn5mutants showing enhanced symbiotic effectiveness. Microbiology, 1994, 140: 463-470 (doi: 10.1099/00221287-140-3-463).

3. Provorov N.A., Onishchuk O.P., Yurgel' S.N., Kurchak O.N., Chizhevskay a E.P., Vorob'e v N.I., Z at ovskay a T.V., S i m a rov B.V. Genetika, 2014, 50(11): 1273-1285 (doi: 10.7868/S0016675814110113).

4. Onish chuk O.P., Kurchak O.N., Sharypova L.A., Provorov N.A., Simarov B.V. Genetika, 2001, 37: 1507-1512.

5. Rumyantseva M.L., Simarov B.V., Onishchuk O.P., Andronov E.E., Chizhevskaya E.P., B lova V.S., Kurchak O.N., Muntyan A.N., Rum y a nts e va T.B., Z at ovsk y a T.V. Biologicheskoe raznoobrazie kluben'kovykh bakterii $v$ ekosistemakh $i$ agrotsenozakh. Teoreticheskie osnovy $i$ metody [Nodule bacteria biodiversity in ecosystems and agrocenoses. Theoretical basis and methods]. St. Petersburg, 2011.

6. S a g u l e n k o E.A., S ha r y p ov a L.A., K ro l' E.A., S i m a rov B.V. Genetika, 1998, 34: 903-907.

7. Chizhevskaya E.P., On ishchuk O.P., Sharypova L.A., S i marov B.V. Isolation and characterization of a gene involved in control of nodulation competitiveness of Sinorhizobium meliloti strain CXM1-105. Proc. $11^{\text {th }}$ Int. Congr. on molecular plantmicrobe interactions. I.A. Tikhonovich., B.J.J. Lugtenberg, N.A. Provorov (eds.). St. Petersburg, 2004: 549-553.

8. Maniatis T., Frich E., S a mbruk J. Metody gennoi inzhenerii. Molekulyarnoe klonirovanie [Methods in gene engineering. Molecular cloning]. Moscow, 1984.

9. Provorov N.A., Andronov E.E., Onishchuk O.P., Kurchak O.N., Chizh e v s k a y E.P. Mikrobiologiya, 2012, 81: 244-253.

10. La k i n G.F. Biometriya (4-e izdanie) [Biometry]. Moscow, 1990.

11. Finan T.M., McWhinnie E., Driscoll B.T., Watson R.J. Complex symbiotic phenotypes result from gluconeogenic mutations in Rhizobium meliloti. Mol. Plant Microbe Interact., 1991, 4: 386-392.

12. Cevallos M.A., Encarnacion S., Leija A., Mora Y., Mora J. Genetic and physiological characterization of a Rhizobium etli mutant strain unable to synthesize poly-betahydroxybutyrate. J. Bacteriol., 1996, 178: 1646-1654.

13. Yu rge l' S.N., S hary p ov a L.A., S i m a r o v B.V. Genetika, 1998, 34: 737-741.

14. Yurgel S.N., Kahn M.L. Dicarboxylate transport by rhizobia. FEMS Microbiol. Rev., 2004, 28: 489-501 (doi: 10.1016/j.femsre.2004.04.002). 
15. Mille r S.H., Elli ot R.M., Sulliva n J.T., Ro ns o n C.W. Host-specific regulation of symbiotic nitrogen fixation in Rhizobium leguminosarum biovar trifolii. Microbiology, 2007, 153: 3184-3195 (doi: 10.1099/mic.0.2007/006924-0).

16. Bonaldi K., Gourion B., Fardoux J., Hannibal L., Cartieaux F., Boursot M., Vallenet D., Chaintreuil C., Prin Y., Nouwen N., Giraud E. Large-scale transposon mutagenesis of photosynthetic Bradyrhizobium sp. strain ORS278 reveals new genetic loci putatively important for nod-independent symbiosis with Aeschynomene indica. Mol. Plant Microbe Interact., 2010, 23: 760-770 (doi: 10.1094/MPMI-23-6-0760).

17. Oni sh chuk O.P., Vorob'ev N.I., Provorov N.A., S i m arov B.V. Ekologicheskaya genetika, 2009, 7(2): 3-10.

18. Onishchuk O.P., Sharypova L.A., Kurchak O.N., Bekker A., Si marov B.V. Genetika, 2005, 41: 1617-1623.

19. Pobigaylo N., Szymczak S., Nattkemper T.W., Becker A. Identification of genes relevant to symbiosis and competitiveness in Sinorhizobium meliloti using signaturetagged mutants. Mol. Plant-Microbe Interact., 2008, 21: 219-231 (doi: 10.1094/MPMI-212-0219).

20. Williams A., Wilkinson A., Krehenbrink M., Russo D.M., Zorreguieta A., D o w ni e J.A. Glucomannan-mediated attachment of Rhizobium leguminosarum to pea root hairs is required for competitive nodule infection. J. Bacteriol., 2008, 190: 4706-4715 (doi: 10.1128/JB.01694-07).

21. van Dillewijn P., Soto M.J., Villad as P.J., To ro N. Construction and environmental release of a Sinorhizobium meliloti strain genetically modified to be more competitive for alfalfa nodulation. Appl. Environ. Microbiol., 2001, 67: 3860-3865 (doi: 10.1128/AEM.67.9.38603865.2001)

22. D i ng H., Y ip C.B., Ge d des B.A., Ores nik I.J., H y nes M.F. Glycerol utilization by Rhizobium leguminosarum requires an $\mathrm{ABC}$ transporter and affects competition for nodulation. Microbiology, 2012, 158: 1369-1378 (doi: 10.1099/mic.0.057281-0). 